\title{
多視点カメラによる監視システムの状況把握効率向上
}

\section{Improving the Situation Assessment Efficiency of Monitoring Systems Using Multiple Cameras}

\author{
学生会員 村 松 孝 治 ${ }^{\dagger *}$, \\ 山下 淳†5, \\ 小林一 郎 ${ }^{\dagger 2}$, 正会員 谷川智 洋 $† 3, \uparrow 4$, \\ 広田 光一 ${ }^{\dagger 4}+6$, 廣 瀬 通 孝 ${ }^{\dagger 4}$
}

Koji Muramatsu $^{\dagger 1 *}$, Ichiro Kobayashi ${ }^{\dagger 2}$, Tomohiro Tanikawa ${ }^{\dagger 3, \dagger 4}$, Jun Yamashita ${ }^{\dagger 5}$, Koichi Hirota ${ }^{\dagger 4, \dagger 6}$ and $^{-1}$

Michitaka Hirose ${ }^{\dagger 4}$

\begin{abstract}
Currently, video cameras with high performance and high resolution have been getting cheaper, and the number of video cameras positioned in various places has increased. With this background, we have done research with the aim of improving the situation assessment efficiency when observing multiple video images from multiple monitoring cameras. In this paper, we propose a system that generates mixed video images to see both obstacles and the obscured views behind them, using multi-viewpoint images from multiple outdoor cameras arranged to record images of the same space from different perspectives. Additionally, we evaluate and report the validity of this system.
\end{abstract}

キーワード : ビデオカメラ 障害物消去 複合現実感

\section{1. ま え がき}

近年, ビデオカメラ技術の進歩に伴い, 高性能・高画質

2004 年 9 月 8 日, 日本バーチャルリアリティ学会第 9 回大会で発表

2004 年 12 月 24 日受付, 2005 年 3 月 22 日最終受付, 2005 年 4 月 11 日 採録

$\dagger 1$ 東京大学 大学院 工学系研究科

（T 153-8904 目黒区駒場 4-6-1, TEL 03-5452-5197）

$\dagger 2$ 日本電気株式会社

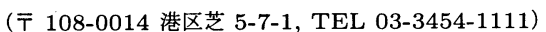

$\dagger 3$ 独立行政法人 情報通信研究機構 駒場 SVR リサーチセンター

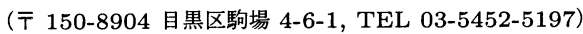

$\dagger 4$ 東京大学 先端科学技術研究センター

（ ₹ 153-8904 目黑区駒場 4-6-1, TEL 03-5452-5197）

$\dagger 5$ 筑波大学 大学院 システム情報工学研究科

（テ 305-8573 つくば市天王台 1-1-1，TEL 029-853-5800)

76 東京大学 大学院 新領域創成科学研究科

(T 113-0033 文京区本郷 7-3-1, TEL 03-5841-6366)

$*$ 東京大学 大学院 工学系研究科

$\dagger 1$ Graduate School of Engineering, The University of Tokyo

(4-6-1 Komaba, Meguro-ku, Tokyo 150-8904, Japan)

$\nmid 2$ NEC Corporation

(5-7-1 Shiba, Minato-ku, Tokyo 108-0014, Japan)

$\nmid 3$ Komaba SVR Research Center, National Institute of Information and Communications Technology

(4-6-1 Komaba, Meguro-ku, Tokyo 150-8904, Japan)

$\dagger 4$ Research Center for Advanced Science and Technology, The University of Tokyo

(4-6-1 Komaba, Meguro-ku, Tokyo 150-8904, Japan)

$\lceil 5$ Graduate School of Systems and Information Engineering, The University of Tsukuba

(1-1-1 Tenoudai, Tsukuba-shi, Ibaraki 305-8573, Japan)

†6 Graduate School of Frontier Sciences, The University of Tokyo

(7-3-1 Hongo, Bunkyo-ku, Tokyo 113-0033, Japan)

* Graduate School of Engineering, The University of Tokyo
のビデオカメラの価格が低下しており, ビデオカメラの設 置台数, その中でも特に監視カメラの設置台数が増加して きている。これにより, 多地点におけるカメラ映像が入手 可能となるが, 膨大な数のカメラ映像をすべて同時に監視 するのは困難であり, このため, 状況把握を効率よく行う ための手段が求められてきている.

カメラ設置台数の規模や, 把握すべき状況の種類により, この課題の持つ意味は変わってくる. まず, 単一の監視対 象空間を対象とする場合は, 単一のコンテキスト (ここで は, 単一の場所で起きている事象をさす) を部分的に捉えた 複数の映像を如何に融合して全体像を把握するか, などが 重要となる. 次に, 複数の監視対象空間に設置したカメラ 映像を対象とする場合は, 同時進行する複数のコンテキス 卜を如何に効率よく把握するか, などが重要となる. 我々 のグループでは, まずは前者に注目し, 複数のカメラ映像 をシームレスに (連続的に境界なく) つなぎ, また, 効率よ く融合させて状況把握効率を向上することを目的とした研 究に取り組んでいる.

\section{2. 関 連 研 究}

単一の監視対象空間を対象に状況把握効率を向上する他 の研究例としては，川崎らが監視対象空間をいろいろな位 置から撮影した多視点映像を用いて 3 次元モデルを構成し, 自由な視点位置からの映像を生成・提示する研究を行って いる ${ }^{1)}$ 。しかし，監視対象空間を囲む壁には，別途用意し 
た CAD データが適用されるため, 監視対象空間を囲む壁 付近の映像情報, すなわち, 壁の模様やガラス空, 壁に張 り付いている額, 壁に接した棚などに関する映像情報はリ アルタイムな情報ではない。 また, 監視対象空間の CAD データの準備も必要となる.

そこで我々は，多視点映像を元に自由な視点位置からの 映像をリアルタイムに生成・提示して利用者に空間を認識 させる監視システムを目指し，また，特に，監視対象空間 を囲む壁付近の映像情報をリアルタイムな映像情報とする ために必要な手段として, 障害物を消去した映像の生成に 注目した研究を進めてきている ${ }^{2) 3)}$.

障害物消去の他の研究例としては, まず, Zokai らが, カ メラが正確にキャリブレーションされていることを前提に, 障害物を他のカメラからの背景画像に入れ替えて, 障害物 消去画像を生成する研究を行っている ${ }^{4)}$. しかし, 監視対 象空間に多数のカメラを配置する場合には, カメラを新た に設置する時や, 監視対象の変化によりカメラの位置/向き を変更する時, 悪意のある人によりカメラの位置/向きが不 当に変えられた時, カメラの位置/向きがずれた時などに 毎回キャリブレーションが必要となり, 手間がかかってし まう。

また, Kameda らがカメラ付 PDA の映像と定点カメラ の映像を融合して透視する研究を行っている ${ }^{5}$. しかし, こ の研究ではPDA のカメラのキャリブレーションを行うのに ランドマーク (空の隅等) を利用しており、このランドマー クを自動認識するのに建物の CAD データを利用している. このため, 監視対象空間の CAD データを予め準備する必 要があり, 手間がかかってしまう.

以上の背景から, 今回, 我々は, 多数のカメラを配置し た監視対象空間内で, $\mathrm{CAD}$ データを使用することなく, 人 手によるキャリブレーションの手間が少なく, かつ, 障害 物の消去/半透明化をリアルタイムに行って状況把握効率の 高い映像を提示する監視システムの検討を行った. そして, 特に今回は 2 レイヤ(障害物と障害物のない層)を扱うシス テムを検討した.

また, 今回我々は, 状況把握効率の向上に向け, 障害物 領域の半透視化というアプローチを行っているが，一方で, 障害物領域を半透視化すると, 情報量が増える反面, 障害 物領域で重なり (例えば, 人物と柱の重なり, 人物と人物の 重なり等) が生じ, 見づらい画像になる. しかし, フレーム レートが高ければ，重なった人物等の動きを目で追えるよ うになり，この見づらさをある程度補うことができる．この ため, 半透視化映像を提示する監視システムでは, フレー ムレートの高さが重要となる. また, フレームレートが高 ければ, 人物が素早く動く場合, 特に, 複数の人物が動いて そのうちの一人が万引きを一瞬のうちに行う，というよう な場合にも有用と考えられる. 以上の観点から, 今回のシ ステムでは, 高いフレームレートの実現に重点を置き, 画 質の議論は行わないものとする.

\section{3. 提 案 手 法}

\section{1 障害物消去/半透視化のリアルタイム性追求}

障害物消去/半透視化は,

・障害物の映ったカメラ画像 (以下, 視点画像)

・障害物の背後の映った他カメラの画像

(以下, 補完用画像)

の 2 画像を入力とし, 障害物の背後の各画素を視点画像の 障害物領域の各画素に重悋合わせた画像を出力とすること で実現する.ここで，障害物領域は手動により指定する.ま た, 視点画像之補完用画像における画素の対応付けは, 補 完用画像に射影変換を行うことで行う．射影変換は，事前 にカメラ間の射影変換行列を求めておけば高速に行うこと ができ, リアルタイム処理が必要な本研究に適しているた めである.また, 前述の画素の重㸚合わせは, 視点画像と 補完用画像の各々の画素を一定の割合ずつ(例えば, $40 \%$ : 60\%)にして足すことで行う.これにより半透視化画像を 生成でき, 生成画像に含まれる情報量の増加を期待できる.

なお，射影変換行列はカメラの相互の位置関係により定 まるため, カメラを配置/再配置する段階で求める. また, 人手による手間がかからないよう, 自然特徵点の自動対応 付けを利用して自動算出する.ここで, 自動算出には, 木山 ら及び金澤らの手法 ${ }^{677)}$ を用いている. これらの手法では, 画像内から, より多くの特徵点を含む平面部分に含まれる 特徵点を投票により自動的に選び出し, 対応付け, 射影変 換行列の算出を行う。この手法により, 平面シーンの一部 に非平面物体が含まれていたり, 壁と床などの 2 平面が存 在するシーンであっても, 画像内で平面部分（壁など）の 特徵点数が多ければ良好な結果が得られる.このため, 提 案手法では領域分割処理等の他の手法を組合せることはし ていない, しかし, 逆に, 壁と床などの 2 平面が存在する シーンで床の特徴点数が多い場合には, 床に対して最適な 射影変換行列が算出されてしまい, 障害物領域の重㸚合わ せ時にずれが生じて画質が低下する可能性がある.このた め, 監視カメラは, シーンの背景（壁など）の割合が他の 平面（床など）の割合よりも高くなるよう設置する必要が ある。

また，この射影変換行列の算出により，カメラ視線およ びカメラ位置に関するキャリブレーションは不要となる.こ のため, カメラの設置時やカメラの位置/向きの変更時など に必要な作業は, 射影変換行列の自動算出のみとなり, 人 手によるキャリブレーションの手間を削減することができ る.

一方，射影変換行列を用いることの制約として，障害物 が背景あるいは撮影対象よりも充分手前に位置しているこ と, および, 背景が単一平面もしくは遠景のように単一平面 と近似できることが前提となるが，監視カメラは主に建造 物壁面など平面で構成されることの多い都市空間を対象と しており, 撮影画像内で背景平面の占める割合が高いケー 
スも少なくないことから，適用範囲は狭くはないと考えら れる.また，広角レンズ使用時はレンズ歪みの影響が出て くるが，現時点では通常のレンズを想定しており，レンズ 歪み補正はまだ実装していない.

また，射影変換行列を自動算出することの制約として，手 間を省ける反面，画質の低下が生じることがある，具体的 には, 計算誤差や自然特徵点の誤対応により, 射影変換行 列に誤差が生じ，障害物領域の重ね合わせ時にずれが生じ て画質が低下することがある．また，背景や障害物に複雑 な図形 (木の枝や葉等) が多く含まれる場合には, 特徴点の 対応付けに失敗して不正な射影変換行列が求まってしまい, 結果として, 障害物領域に不適切な領域の画素を融合して しまうことがある.

\section{2 処理の流れ}

提案手法の処理は以下の三つのフェーズから成り立つ.

（1）初期設定処理

・視点画像とするカメラを利用者が選択

・視点画像に対して利用者が障害物領域を指定

(2) 事前処理

- 視点画像と補完用画像を取得

・障害物領域近傍で自然特徵点を抽出

・同一特徵点を画像間で対応付け (含キャリブレーション)

- 対応特徵点の視差情報から射影変換行列を算出

（3）実時間処理 (各フレームごとに実施)

- 視点画像と補完用画像を取得

- 補完用画像を射影変換

- 変換画像を半透明化

-障害物領域に半透明化した変換画像を重ね合わせる

\section{4. システム構成}

システムは, 映像を撮影するカメラノード部と画像処理 を施して障害物消去映像を生成する統合 PC に大別される. 各々のノードと統合 PC は, イーサネットで結ばれ, 全体 でギガビットネットワークを形成している (図 1). 視点画 像の選択は, 統合 PC にてカメラノードを指定することで 行う. また, 障害物領域の指定は, 統合 PC 上で視点画像 を見ながら，マウスで矩形を指定することで行う. 補完用 画像の選択も統合 PC にてカメラノードを指定することで 行う.

カメラノードは画像の取得, 送信を行う. IEEE1394 カ メラと画像送信用 PC とで構成され, 統合 PC から要求 があれば VGA 画像を 30 [fps] で撮影, 補完用画像の場合 は, 予め統合 PC 部で算出しておいた射影変換行列を施し, TCP/IP により送信する.

統合 PC 部では画像の受信, 処理, 表示を行う. まずフ レーム毎に, 視点画像と補完用画像を撮影しているカメラ ノード部へ映像の伝送を要求する. 受信した補完用画像を視 点映像の障害物領域に重ね合わせて, 障害物消去画像を生 成, 表示する。表示までの一連の処理を終えた後に次の映

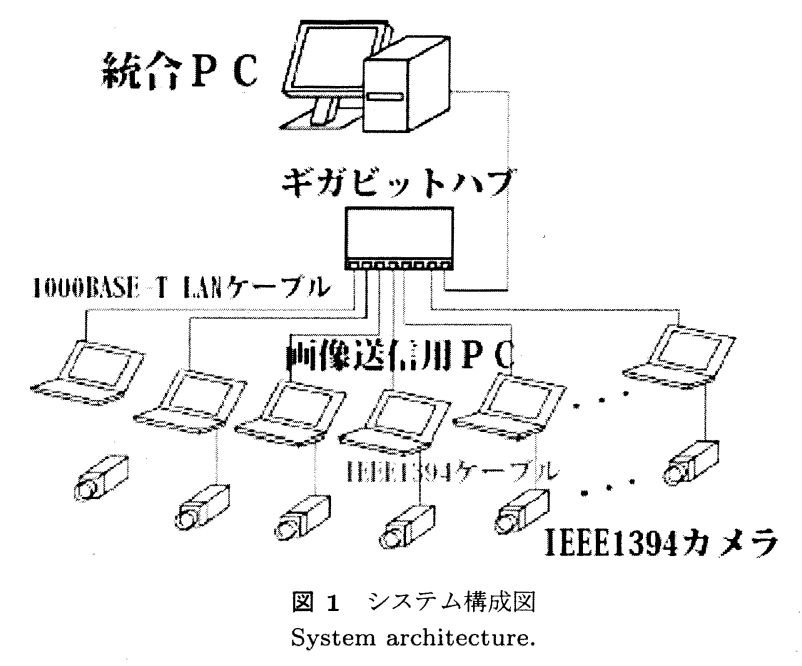

像の伝送を要求する.

画像の解像度は $640 \times 480$ で, 統合 PC は Xeon $3.20 \mathrm{GHz}$ $\times 2+メ モ リ ー 3.5 \mathrm{~GB}$, 画像送信用 PC は PentiumM $1.60 \mathrm{GHz}+メ モ リ ー 640 \mathrm{MB}$ である. OS は共に Linux で,レンダリングには OpenCV-0.9.5 を使用した. 全カメ ラノードでレンズ仕様は同じであり，垂直画角 36 度，水平 画角 47 度，対角画角 57 度である.

\section{5. 実験と評価}

本校構内の中庭 (屋外) にて, 障害物 (柱) の手前と背後に 一人ずつの人物が移動するシーンを撮影した．障害物 (柱) の正面を向くように, カメラノード (視点画像用) を設置し, このカメラノードの左右に約 $80 \mathrm{~cm}$ 間隔で他のカメラノー ド (補完用画像用) を 8 台ずつ一列に設置した.ここで, 補 完用画像用カメラノードは，障害物領域あるいはその背後 が撮影できる方向に設置している. 補完用画像としては, 視 点画像の 7 台左 (約 $5.6 \mathrm{~m}$ 左) のカメラノードから撮影した 画像を使用した. 視点画像と補完用画像, および、それぞ れの自然特徵点の抽出および対応付け結果 (図 2), 射影変 換適用後の補完用画像 (図 3), 障害物半透視化画像 (図 4) を図に示す.

図 4 において, 障害物 (柱) の手前と背後の人物が同時 に映っており, 視点画像と補完用画像の情報量を網羅する, 状況把握効率の高い映像を提示できていることがわかる. また, 今回の実験における撮影フレームレートは約 29.97 [fps] であり, リアルタイム性をほぼ実現できている. 以上 から，本手法が有効であることが確認できた.

\section{6. むす び}

本論文では, 多数のカメラを配置した監視対象空間にお いて，キャリブレーションの手間が少ない，障害物の消去/ 半透明化を行う監視システムを提案し, 実時間性を満足し ており, また, 状況把握効率向上のために有効であること を示した。

今後は, 人物などの移動体が障害物となるような動的な 

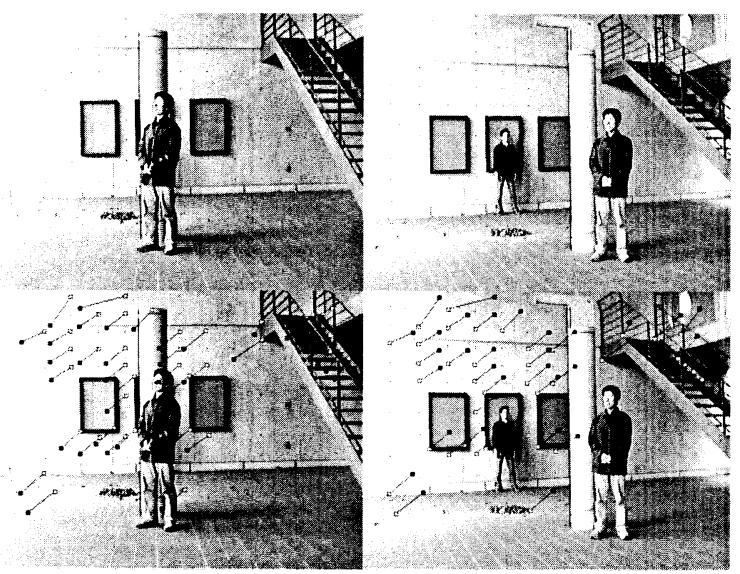

図 2 視点画像 (左上), 補完用画像 (右上), 各々の自然特徵点 の対応付け結果 (左下, 右下)

A viewpoint image (upper left), an image for assistance (upper right), and results of matching natural feature points of those images (lower left and lower right).

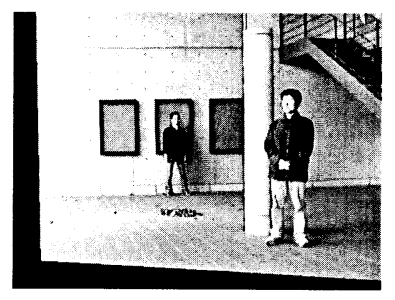

図 3 射影変換適用後の補完用画像

An image for assistance converted by a projection matrix.

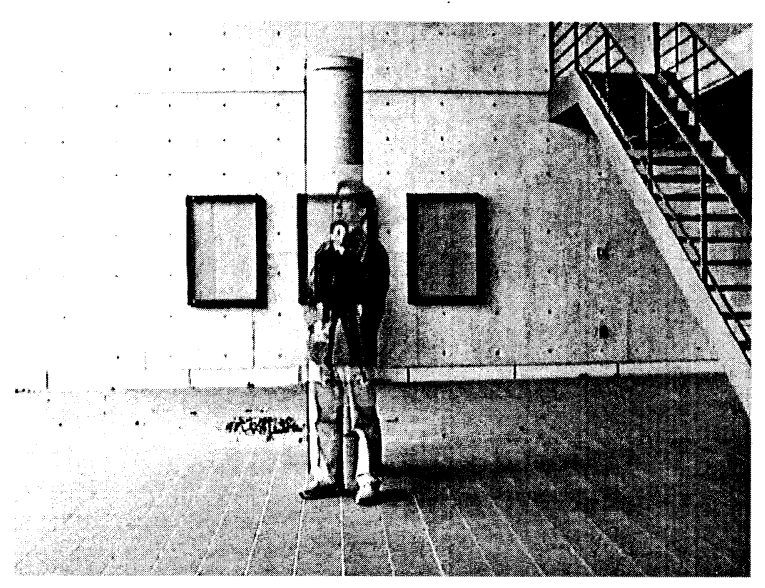

図 4 障害物半透視化画像

An image with a see-through obstacle.

状況に対応していく予定である. また, 長期的展望として, 単一の監視対象空間の状況把握向上の成果を元に, 複数の 監視対象空間に設置したカメラ映像を対象とする場合にも 対応していく予定である.

本研究の一部は, 文部省の科学研究費補助金 (基礎研究 (A)(2), 課題番号 15200008) の助成によった. 記して謝意
を表す。

\section{[文献]}

1）川崎直之, 高井昌彰 : 複合現実感によるビデオ監視，日本バーチャルリ アリティ学会第 7 回大会論文集, pp.429-430 (2002)

2）村松孝治, 小林一郎, 谷川智洋, 山下淳, 広田光一, 廣瀬通孝: 多視点 カメラによる自由視点監視システム，日本バーチャルリアリティ学会第 9 回大会論文集, pp.52-52 (2004)

3）小林一郎, 村松孝治, 谷川智洋, 山下淳, 広田光一, 廣瀬通孝: 超多眼 カメラによる障害物消去に関する研究，日本バーチャルリアリティ学会 第 9 回大会論文集, pp.56-56 (2004)

4) Siavash Zokai, Julien Esteve, Yakup Genc, Nassir Navab : Multiview Paraperspective Projection Model for Diminished Reality, Proc. of ISMAR2003, pp. 217-226 (2003)

5) Yoshinari Kameda, Taisuke Takemasa, Yuichi Ohta: "Outdoor See-Through Vision Utilizing Surveillance Cameras", IEEE and ACM International Symposium on Mixed and Augmented Reality (ISMAR04), pp.151-160 (2004)

6）木山真伸，太田直哉，金谷健一: 2 台のカメラと射影変換を用いた進入 者検出, 情報処理学会研究会報告,99-CVIM-118-8, pp.53-58 (1999)

7）金澤靖, 金谷健一：段階的マッチングによる画像モザイク生成, 信学論 J86-D-II, 6,pp.816-824 (2003)

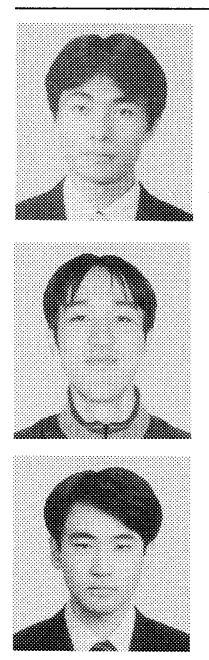

狩松素治 1994 年, 東京大学 工学部 産業機械工 学科卒業. 1996 年, 同大学 大学院 産業機械工学専攻 修士課程 修了. 同年, 株式会社 東芝入社, 2003 年, 東 京大学 大学院 工学系研究科 博士課程 入学. 多視点カメ ラに関する研究に従事. 学生会員.

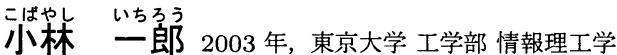
部 卒業. 2005 年, 東京大学 大学院情報理工学系研究 科修士課程 修了. 同年, 日本電気株式会社 入社.

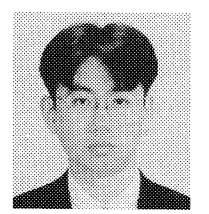

㗉妿智洋 1997 年, 東京大学 工学部 産業機械工 学科卒業. 1999 年, 同大学大学院 工学系研究科機械 情報工学専攻 修士課程 修了. 2002 年, 同大学 博士課 程 修了. 同年, 通信・放送機構研究員.イメージ・ベー スト・レンダリング，MRに関する研究に従事. 博士 (工 学). 正会員.

やまに卡 监 1999 年, 筑波大学大学院 修士課程 理工学研究科修了. 2002 年, 同大学 大学院博士課程 工学研究科 単位取得退学. 同年, 東京大学 先端科学技 術研究センター特任助手. 2005 年, 筑波大学 大学院 シ ステム情報工学研究科 講師. 共同作業支援 (CSCW), グ ループウェア, 五感情報通信の研究に従事. 博士 (工学)

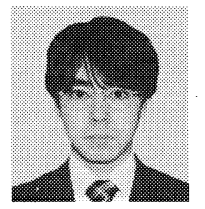

広笛 光光んち 1988 年, 東京大学工学部 産業機械工 学科 卒業, 1990 年, 同 大学院 産業機械工学専攻 修士 課程 修了, 1994 年, 同 博士課程 修了, 1995 年, 豊橋 技術科学大学情報工学系助手, 2000 年, 東京大学 先 端科学技術研究センター助教授. 2005 年, 東京大学 大 学院 新領域創成科学研究科 助教授. 主にヒューマンイ ンタフェースの研究に従事. 工学博士.

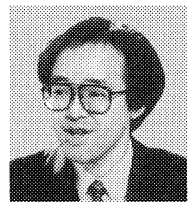

廣瀬通势 1982 年, 東京大学大学院博士課程 修了. 同年, 東京大学 工学部 産業機械工学科 専任講師. 1983 年, 同大学 助教授. 1999 年, 東京大学 大学院 I 学系研究科機械情報工学専攻 教授. 同年, 東京大学 先端 科学技術研究センター 教授. 主にシステム工学, ヒュー マンインタフェース，バーチャルリアリティの研究に従 事. 工学博士. 